\title{
DNA as a Recyclable Natural Polymer
}

Weina Liu, Simone Giaveri, Daniel Ortiz, Francesco Stellacci*

W. Liu, S. Giaveri, F. Stellacci

Institute of Materials, École Polytechnique Fédérale de Lausanne (EPFL), Lausanne 1015, Switzerland.

Institute of Bioengineering, École Polytechnique Fédérale de Lausanne (EPFL), Lausanne

1015, Switzerland.

E-mail: francesco.stellacci@epfl.ch

\section{Ortiz}

Institute of Chemical Sciences and Engineering, École Polytechnique Fédérale de Lausanne (EPFL), Lausanne 1015, Switzerland.

Keywords: DNA hydrolysis, one-pot phosphorylation, DNA recycling, qPCR

\section{Abstract}

Nature has the ability of circularly re-using its components to produce molecules and materials it needs. An example is the ability of most living organisms of digesting proteins they feed off into amino acids and then using such amino acids in the ribosomal synthesis of new proteins. Recently, we have shown that such recycling of proteins can be reproduced outside living organisms. The key feature of proteins that allows for this type of recycling is their being sequence-defined polymers. Arguably, the most famous sequence-defined polymer in Nature is DNA. Here we show that it is possible starting from sheared calf-DNA to obtain all the four nucleotides as monophosphate-nucleotides (dNMPs). These dNMPs were phosphorylated in a one-pot, multi-enzymes, phosphorylation reaction to generate triphosphate-nucleotides (dNTPs). Finally, we used the dNTPs so achieved (with a global yield of $\sim 60 \%$ ) as reagents for PCR (polymerase chain reaction) and quantitative PCR (qPCR) to produce target DNA strands. This approach is an efficient, convenient, and environmentally friendly way to produce dNTPs and DNA through recycling according to the paradigm of circular economy. 


\section{Introduction}

Nature can efficiently break down complex biomass into small molecules and circularly use them to fulfill its requirement of biosynthesis, a recycling masterpiece. For example, bacteria in stomach-intestinal system can efficiently digest food to obtain nutrition molecules for the synthesis of bioactive macromolecules. ${ }^{[1]}$ Also, microorganisms used in fermentation processes can degrade organic nutrients to alcohol or other small molecules. Those functions have been widely utilized in alcoholic beverages or dairy industry, ${ }^{[2,3]}$ while most other approaches that Nature has to 'recycle' proteins and nucleic acids have not yet been translated in laboratory settings. Recently we have shown that it is possible to reproduce outside living organisms the approach organisms use to 'recycle' mixtures of $n$ proteins into the $(n+1)^{\text {th }}$ protein of interest, not necessarily related to the parent ones ${ }^{[4]}$ Briefly, protein mixtures were first enzymatically digested into their constitutive amino acids, and then a cell-free transcription-translation system was used to recycle the so obtained amino acids into fluorescent (GFP, mScarlet-i), or bioactive

proteins (catechol 2,3-dioxygenase), by means of the ribosomal expression. Recycling unseparated mixtures of proteins into the protein of need, not necessarily related to the parent materials, can only work for sequence-defined polymers, where function derives from the sequence of monomers.

DNA is also a sequence-defined polymer where function derived from the exact order of the four nucleotides (bases) that determine its sequence. Hence, following the same principles illustrated for the proteins/amino acids system, one can conceive an approach where a random mixture of DNA can be 'digested' into its nucleotides that can then be put back together into a new DNA sequence unrelated to the original one. In the case of DNA the formation of the final DNA product can be made with a man-invented process (polymerase chain reaction, PCR) ${ }^{[5]}$ 
When compared to protein recycling, DNA recycling requires an extra step. ${ }^{[6]}$ DNA can be depolymerized through an enzymatically hydrolysis step to break inter-nucleotide phosphodiester backbone, but the product of such reaction are monophosphate-nucleotides (dNMPs). Unfortunately, dNMPs cannot be directly used as reagents to produce new DNA sequences, one needs to first convert them into triphosphate-nucleotides (dNTPs) by introducing additional phosphate groups. In this work, we used Nature available DNA (calf DNA) as a starting material to mimic the Nature' recycling of DNA. We first established a method to depolymerize DNA into dNMPs with efficiency exceeding $80 \%$. We then developed a convenient, efficient synthesis to phosphorylate the mixture of the four dNMPs into the respective dNTPs with yields of 88\% (commercialized dNMPs) and 70\% (recycled dNMPs). Finally, we proved that the so produced dNTPs could be used for the biosynthesis of new DNA sequences by PCR amplification, and for nucleic acid testing by quantitative PCR (qPCR). This methodology could bring a totally new path to obtain monomeric nucleotide materials, which might replace their chemical synthesis. ${ }^{[7]}$

\section{Result and discussion}

\subsection{DNA De-polymerization}

Nature is a vast storage of polymeric DNA materials, e.g., the maximum DNA content can be $10 \%$ (dry mass basis) from bacterioplankton. ${ }^{[8]}$ Also, Nature can rapidly and constantly produce DNA, which can be considered as a sustainable resource to recycle monomeric nucleotide materials. In this work, commercially available calf thymus DNA (calf DNA) with known content of CG $41.9 \%$ and AT 58.1\% (specifications from Sigma-Aldrich) was used as a natural DNA source for the enzymatic hydrolysis to obtain nucleotide monomers (Figure 1a). To efficiently hydrolyse calf DNA and release dNMPs, it is important to choose the cleavage site at 3'-terminal of the phosphodiester bonds, so that the monophosphate group can be kept at 5'- 
terminal of the released monomeric nucleotides. To obtain the desired hydrolysis product, we chose Exonuclease III (Exo III) and Exonuclease I (Exo I) with the required 3'phosphomonoesterase activity. Exo III is a double-strand DNA (dsDNA) specific exonuclease, which can catalyze the stepwise removal of dNMPs from 3'-terminal of dsDNA with blunt end or $5^{\prime}$ - overhang. ${ }^{[9,10]}$ Exo I is a single-strand DNA (ssDNA) specific exonuclease, which can catalyze the stepwise removal of dNMPs from ssDNA in the $3^{\prime}$ - to $5^{\prime}$ - direction. ${ }^{[11]}$ The mixture of calf DNA, Exo III, and Exo I was incubated in 1x Exo III buffer at $37^{\circ} \mathrm{C}$ overnight for hydrolysis (Figure 1a, step 1). Afterwards, unhydrolyzed, and hydrolyzed calf DNA were loaded to a $2 \%$ agarose gel. In Figure $1 \mathrm{~b}$ we show a representative image of a gel containing the starting materials as well as the hydrolyzed one. The initial calf DNA shows a smeared band (lane 2, sequence length between 100-2000 and above 2000 base pair), the hydrolyzed one has an almost absent band (lane 3), indicating the relatively high hydrolysis efficiency.

To identify the DNA hydrolysis product, and to determine the hydrolysis efficiency, we used LC-MS for qualitative as well as quantitative analysis. The calibration curves from dNMPs standard solutions can be found in supporting information (Figure S1a). The plot of XIC (extracted-ion chromatogram) of the hydrolysis product is shown in Figure 2b. It illustrates that the mixture of Exo III and Exo I could efficiently hydrolyze DNA to release dNMPs. The average hydrolysis efficiency of four dNMPs was $83.9 \pm 0.6 \%$ (Figure S1b). The possible reason of non-completely hydrolysis could be the hydrolysis efficacy of nuclease Exo III, which can hydrolyze dsDNA with blunt end and 5'- overhang but cannot hydrolyze dsDNA with 3'overhang. As the calf DNA was mechanically sheared, it was not possible to exclude the existence of dsDNA with 3'-overhang in the starting material of the DNA hydrolysis reaction. Overall, the calf DNA hydrolysis was relatively efficient with desired product and high yield. The established hydrolysis method is non-selective for sequence; hence we believe that it will be applicable to all kinds of sheared DNA. 


\subsection{One-pot dNMPs phosphorylation}

As previously mentioned, the DNA hydrolysis products dNMPs could not be directly applied for the biosynthesis of new DNA sequence, as this required dNTPs. To address this problem, we implemented a phosphorylation step to convert the dNMPs into dNTPs. Since the DNA hydrolysis product was a mixture of four dNMPs, it was important to establish a phosphorylation approach that could convert the four dNMPs into dNTPs in a one-pot reaction. We looked for a multi-enzymes bio-catalysis as an efficient approach. ${ }^{[12,13]}$ In the biosystem, the phosphorylation of nucleotides is catalyzed by intracellular phosphotransferase and kinase. ${ }^{[14,15]}$ Therefore, cell lysate is an excellent catalyst and has been applied for this nucleotide phosphorylation reaction, ${ }^{[16,17]}$ but the reported phosphorylation yields are relatively low (especially for dTTP). We thought that a possible reason for such low yields could be the imbalanced content of four nucleotides in the intracellular nucleotide pool. It is known that such pool is rich in A and $\mathrm{G}$ bases as they are also needed for energy storage, signaling and apoptosis. ${ }^{[18]}$ Hence one can postulate that enzymes to phosphorylate the $\mathrm{T}$ and $\mathrm{C}$ bases less present than the ones to perform the same task in the other bases. ${ }^{[19]}$ To improve the phosphorylation yield of this one-pot reaction, we added T4-nucleotide monophosphate Kinase (T4), that can specifically catalyze the phosphorylation of dTMP, dCMP, and dGMP. ${ }^{[20]} \mathrm{We}$ performed the one-pot phosphorylation in an acetyl-phosphate/ATP dual-phosphate-donors system (Figure 1a, step 2, details see insert), with the mixture of E. coli S30 cell extract (S30) and $\mathrm{T} 4$ as catalyst. S30 is a commercial cell lysate extract product, ${ }^{[21-23]}$ that has been originally established for cell-free protein expression. ${ }^{[24]}$ ATP was used as a phosphate donor and a cofactor, that was continuously consumed and re-generated, see insert in Figure 1a. Acetylphosphate (AceP) was applied as the phosphate donor to re-generate ATP. During this phosphorylation step, a phosphate group was introduced to dNMPs, with dNDPs (nucleotide 
diphosphate) formed as intermediate products, and further a second phosphate group was introduced to dNDPs to generate the mixture of dNTPs.

To evaluate the phosphorylation efficiency of this one-pot reaction, as positive control we first performed the reaction with a commercial dNMPs mixtures with equal content of four bases. The enzyme mixture was carefully adjusted to achieve the best phosphorylation efficiency of all four dNMPs. The phosphorylation product referred as dNTPs_dNMPs was quantified by HPLC (Figure 2b-2). ${ }^{[25]}$ Calibration curve from dNTPs and ATP standard solutions are shown in supporting information (Figure S3). A relatively high average phosphorylation yield was achieved $(88.3 \pm 2.3 \%$, Figure $2 \mathrm{c})$, showing that the combination of cell extract and NMP kinase can efficiently catalyze this multi-receptor phosphorylation reaction. The residue of dNMPs, and partially phosphorylated products dNDPs were quite low (see the extra peaks other than dNTPs and ATP with retention time between 3-14 mins in Figure 2b-2 and Figure S2-4). In the phosphorylation mixture, final content of dNTPs was $72.0 \pm 1.6 \%$, dNMPs/dNDPs residue was $9.5 \pm 2.0 \%$, and ATP residue was $18.4 \pm 0.4 \%$ (Figure $2 \mathrm{c}$ ). Quantification of the dNMPs/dNDPs residues was performed from peak area integration.

Further, phosphorylation of recycled dNMPs_calf DNA was performed by the same approach, and the product referred as dNTPs_calf DNA was quantified by HPLC (Figure 2b-3). The average phosphorylation efficiency of dNTPs_calf DNA was calculated to be $69.0 \pm 0.5 \%$. In the phosphorylation mixture, dNTPs_calf DNA content was $57.3 \pm 0.3 \%$, dNMPs/dNDPs residue was $25.7 \pm 0.4 \%$, and ATP residue was $16.9 \pm 0.1 \%$ (Figure $2 \mathrm{c}$ ). There was a $21 \%$ decreased in phosphorylation efficiency of dNTPs_calf DNA in comparison to the dNTPs_dNMPs standards. The possible reason could be the unequal ratio of four nucleobases from recycled dNMPs, which led to unequal catalysis efficiency in this one-pot, competing phosphorylation reaction. Nevertheless, the concentration of all four dNTPs_calf DNA was in 
the range of $190-280 \mu \mathrm{M}$ (in average $243.7 \pm 0.9 \mu \mathrm{M}$, Figure $2 \mathrm{~d}$ ), which was suitable to be directly used for the synthesis of new DNA by PCR. Calculated from the total mass of starting material calf DNA, the average recycling efficiency of dNTPs_calf DNA was $61.5 \pm 0.2 \%$ (all four dNTPs with recycling yield in the range of $58.15 \%-67.28 \%$, Figure $2 \mathrm{e}$ ), which was relatively good after the two steps of hydrolysis and phosphorylation reactions.

\subsection{DNA Re-polymerization}

As a mimic of Nature DNA material circulation, we further re-polymerized the recycled dNTPs_calf DNA into a new DNA sequence by PCR (Figure 1a, step 3). We re-polymerized the recycled dNTPs by PCR amplification of a linear DNA template encoding GFP (Figure 1c, duplicate, lane 2 and 3). Commercially available dNTPs were used as positive control for PCR (Figure 1c, duplicate, lane 4 and 5). The so achieved DNA was purified, and fed into a commonly used cell-free transcription-translation (TX-TL) system ${ }^{[26]}$ (PUREfrex $^{\text {TM }}$, Kaneka Eurogentec SA, see Supporting Information) for verifying the "transcription", and "translation" of the GFP sequence from a DNA template polymerized with recycled nucleotides. Upon feeding a DNA template, the protein of interest was expressed in the TX-TL system. As shown in Figure 1d, a good yield for GFP expression was achieved ( $\sim 80 \%)$, proving that the repolymerized DNA from the hydrolysed DNA precursor encodes a new genetic information for protein expression.

\subsection{Recycling DNA for qPCR}

Quantitative PCR (qPCR) is a powerful molecular diagnose tool to quantify gene expression, ${ }^{[27]}$ which is largely consumed for nucleic acid testing during SARS-CoV-2 pandemic. ${ }^{[28]}$ Since Nature DNA can be efficiently recycled, next, we tested the possibility of using recycled dNTPs 
as substrate for $\mathrm{qPCR}$. The cycles of threshold $\left(\mathrm{C}_{\mathrm{T}}\right)$ are defined as the $\mathrm{qPCR}$ cycle at which the fluorescent signal of the reporter dye crosses an arbitrarily placed threshold, indicating the exponential phase of qPCR amplification. ${ }^{[29]}$ The $\mathrm{C}_{\mathrm{T}}$ inversely depends on DNA amplicon amount in the reaction mixture (the more DNA template, the lower the $\mathrm{C}_{\mathrm{T}}$ value). With equal amount of amplicons, the $\mathrm{C}_{\mathrm{T}}$ value as a reference of the $\mathrm{qPCR}$ performance is influenced by the other components, i.e., the concentration of dNTPs involved in this polymerization process, ${ }^{[30-}$ ${ }^{32]}$ and the content of impurities in PCR substrate. Therefore, in this work the performance of qPCR was used to evaluate the quality of recycled dNTPs.

Since the DNA recycling process is applicable to all genomic DNA, E. coli DNA as an alternative DNA resource was applied for recycling of monomeric dNTPs. The E. coli DNA was hydrolyzed, phosphorylated by the same protocol of calf DNA recycling (details see SI). The recycled product referred as dNTPs_E. coli DNA was also applied for nucleic acid testing by qPCR amplification. Self-made qPCR kits were prepared by mixture of DreamTaq polymerase, Sybr dye, recycled dNTPs (dNTPs_calf DNA or dNTPs_E. coli DNA). The average concentration of dNTPs was adjusted to $0.2 \mathrm{mM}$. Commercially available qPCR kit was applied as positive control. The self-made qPCR kits were used for the amplification of a fragment with 133 base pair from luciferase DNA template. Primers were designed by IDT PrimerQuest ${ }^{\mathrm{TM}}$ Tool. As shown in Figure 3a, similar $\mathrm{C}_{\mathrm{T}}$ values of self-made $\mathrm{qPCR}$ kits and positive control were obtained with low content of DNA template $(0.001 \mathrm{ng})$. With higher content of template DNA (1, 0.1, $0.01 \mathrm{ng})$, the detection performance of self-made qPCR kits was slightly lower than positive control with one or two more circles of $\mathrm{C}_{\mathrm{T}}$ needed (Figure $3 \mathrm{a}$, amplification plots see Figure S4). Since the commercially available qPCR kit (the positive control) is in fully optimized condition, the analytical performance of self-made qPCR kit from recycled dNTPs is still considered relatively good. For the no template control (NTC) sample, the $\mathrm{C}_{\mathrm{T}}$ value of the commercially available qPCR kit was 35.3 , and the self-made qPCR assay 
was 30.8 and 30.4 (qPCR kit prepared from dNTPs_calf DNA and dNTPs_E. coli DNA), respectively. The detect limitation of self-made qPCR kits (template DNA content down to $0.001 \mathrm{ng}$ ) was not affected by NTC results. The qPCR amplification products were loaded to a Page-gel, showing that the amplification products with desired length (Figure 3b). As a molecular diagnosing tool, the preparation of self-made qPCR from recycled dNTPs is relatively convenient and its analytical performance is very good.

\section{Conclusion and outlook}

In this work, we have established an efficient approach to recycle DNA. We have shown that DNA can be de-polymerized to generate dNMPs, that in turn can be phosphorylated to generate dNTPs. The so obtained dNTPs can be re-polymerized by using PCR to achieve a new DNA sequence, hence information, that is completely different from the parent one. The obtained dNTPs can also be used as substrate for qPCR with very good DNA detection performance. Since all the used materials of DNA and enzyme mixtures are abundant in Nature, there is possibility to scale up this process. 
(a)

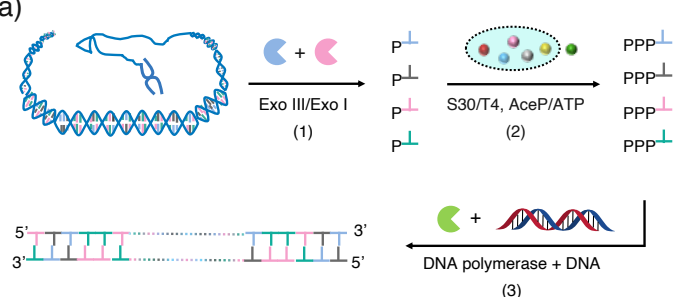

(b)

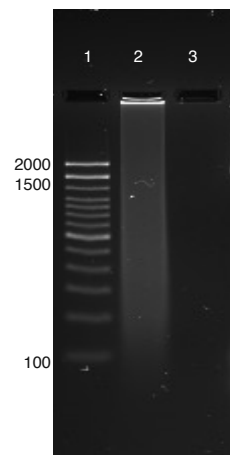

(c)

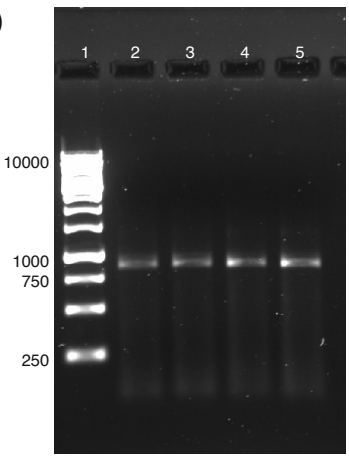

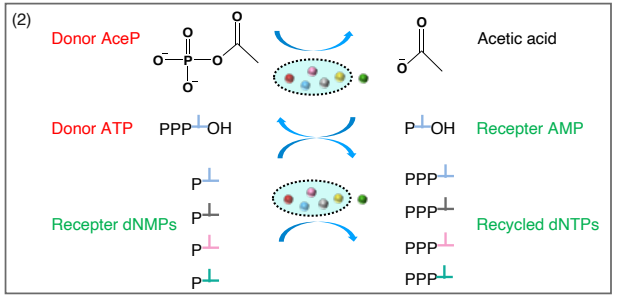

(d)

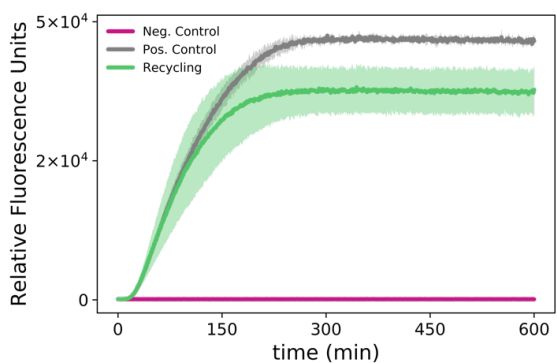

Figure 1. DNA recycling from Nature. (a) Scheme of monomers recycling from calf thymus DNA for PCR, step (1) calf DNA hydrolysis by Exo III and Exo I to release dNMPs, step (2) dNMPs_calf DNA phosphorylation, step (3) PCR to amplify new DNA sequences. The step (2) phosphorylation reaction (insert) was a one-pot reaction catalyzed by mixture of E. coli S30 extract, as E. coli S30 extract was found rich in acetyl kinase ${ }^{[33]}$ and nucleotide mono-/diphosphate kinase, ${ }^{[24,34]}$ and T4 NMP Kinase can catalyze the phosphorylation of dCMP, dTMP and dGMP. (b) Agarose gel (2\%) of ladder (lane 1), calf DNA (lane 2), hydrolyzed calf DNA (lane 3). (c) Agarose gel (1\%) of the PCR amplified GFP sequence from recycled dNTPs (duplicate, lane 2 and 3), as well as from the purchased dNTPs as positive control (duplicate, lane 4 and 5). (d) Plots of the fluorescence signal resulting from the expression of GFP in the TX-TL system. The green curve is obtained by feeding the TX-TL system with a GFP DNA template (75 ng) polymerized from the recycled dNTPs. The grey curve (positive control) is obtained as the result of an expression experiment with the TX-TL system supplemented with a GFP DNA template (75 ng) polymerized from purchased dNTPs. In the negative control expression (violet curve), the TX-TL system was not supplemented with any DNA template. 
(a)

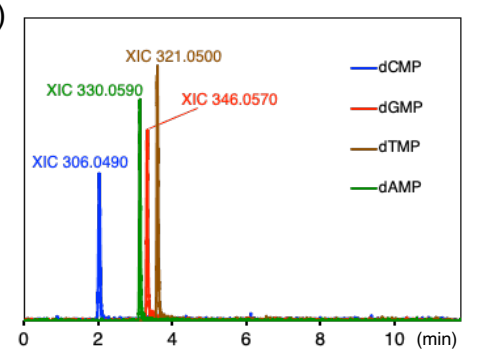

(c)

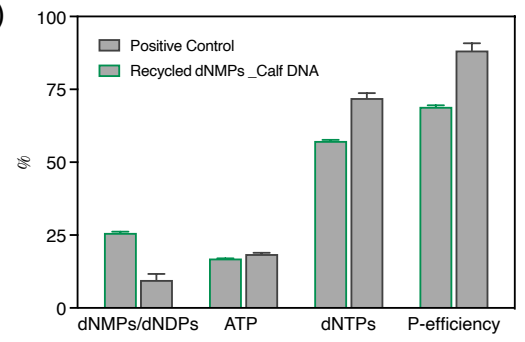

(b)

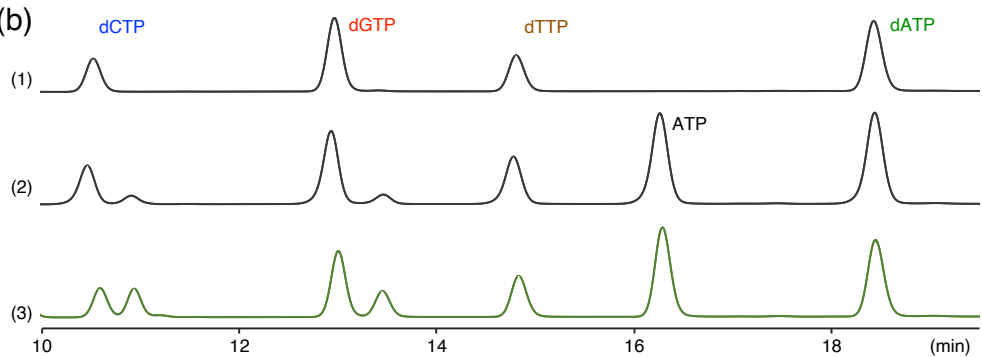

(d)

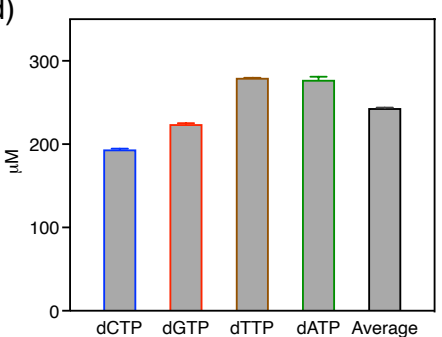

(e)

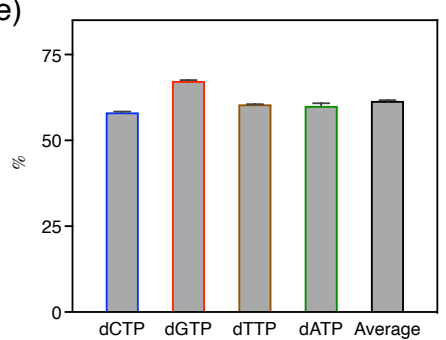

Figure 2. Quantification of calf DNA hydrolysis and dNMPs phosphorylation efficiency by HPLC and HPLC-MS. (a) Extracted-ion chromatogram (XIC) from LC-MS analysis of dNMPs_calf DNA (dAMP_330.0590, dCMP_306.0490,dTMP_321.0500, dGMP_346.0570). (b) HPLC retention time of (1) dNTPs standards, (2) dNTPs_dNMPs phosphorylation, and (3) dNTPs_calf DNA with spectra of full retention time in Figure S2. Small peaks near dCTP and dGTP are non-complete phosphorylation products (dNDPs). (c) Phosphorylation efficiency of dNTPs_dNMPs, dNTPs_calf DNA, with calibration curve in Figure S2. (d) Concentration of recycled dNTPs_calf DNA. (e) Recycling efficiency of dNTPs from calf DNA.

(a)

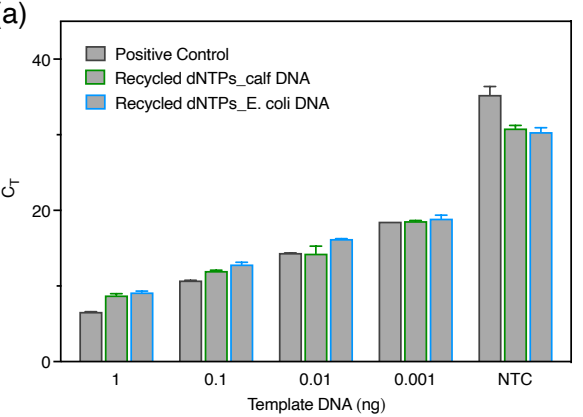

(b)

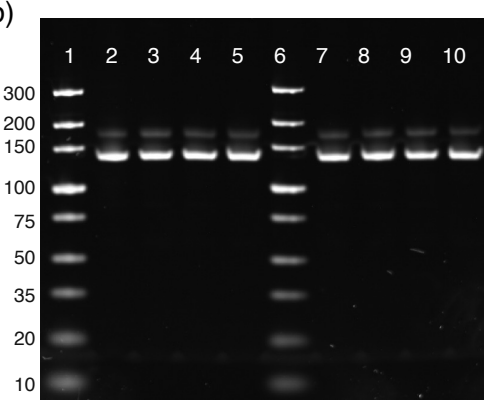

Figure 3. (a) $\mathrm{C}_{T}$ values of self-made qPCR kits from recycled dNTPs_calf DNA and dNTPs_E. coli DNA, with commercially available SybrGreen qPCR kit used as positive control. Plots of all qPCR amplification could be found in supporting information. (b) Page-gel of qPCR amplification products (133 base pair), lane 1 and lane 6, ladders; lane 2-5 and lane 7-10, qPCR amplified DNA products. Self-made qPCR kit was prepared from recycled dNTPs_calf DNA (lane 2-5), and from dNTPs_E.coli DNA (lane 7-10). The content of DNA template was 1, 0.1, $0.01,0.001 \mathrm{ng}$, respectively. 


\section{Supporting Information}

Supporting Information is available from the Wiley Online Library or from the author.

\section{Acknowledgements}

This research has been supported by the SNF Spark project CRSK-2_190167, and by the ERC Advanced Grant (884114-NaCRe). We thank the Core Gene Facility (EPFL) for providing the instruments and training of qPCR. W. Liu thanks Mr. Shiyu Cheng (EPFL_LBNC group) and for the fruitful discussion and Ms. Yueyun Zhang (EPFL_UPBRI group) for the help of qPCR experiment.

\section{Conflicts of interest}

This work is undergoing of patent application.

Received: ((will be filled in by the editorial staff))

Revised: ((will be filled in by the editorial staff)) Published online: ((will be filled in by the editorial staff))

\section{References}

[1] H. N. Munro, J. B. Allison, Mammalian Protein Metabolism., New York And London: Academic Press, 1964.

[2] H. Shigechi, J. Koh, Y. Fujita, T. Matsumoto, Y. Bito, M. Ueda, E. Satoh, H. Fukuda, A. Kondo, Appl. Environ. Microbiol. 2004, 70, 5037.

[3] M. E. Sharpe, Int. J. Dairy Technol. 1979, 32, 9.

[4] S. Giaveri, A. M. Schmitt, L. R. Julià, V. Scamarcio, A. Murello, S. Cheng, L. Menin, D. Ortiz, L. Patiny, S. Bolisetty, R. Mezzenga, S. J. Maerkl, F. Stellacci, bioRxiv 2021, 2020.09.23.309799.

[5] J. M. S. Bartlett, D. Stirling, in PCR Protoc. (Eds.: J.M.S. Bartlett, D. Stirling), Humana Press, Totowa, NJ, 2003, pp. 3-6.

[6] J. Martinussen, M. Willemoës, M. Kilstrup, Compr. Biotechnol. 2011, 91.

[7] B. Roy, A. Depaix, C. Périgaud, S. Peyrottes, Chem. Rev. 2016, 116, 7854.

[8] D. K. Button, B. R. Robertson, Appl. Environ. Microbiol. 2001, 67, 1636.

[9] Q. Xu, A. Cao, L. Zhang, C. Zhang, Anal. Chem. 2012, 84, 10845.

[10] C. D. Mol, C.-F. Kuo, M. M. Thayer, R. P. Cunningham, J. A. Tainer, Nature 1995, 374, 381.

[11] I. R. Lehman, A. L. Nussbaum, J. Biol. Chem. 1964, 239, 2628.

[12] C. D. Richter, D. Nietlispach, R. W. Broadhurst, K. J. Weissman, Nat. Chem. Biol. 2008, $4,75$.

[13] N. C. Dubey, B. P. Tripathi, ACS Appl. Bio Mater. 2021, 4, 1077.

[14] A. N. Lane, T. W.-M. Fan, Nucleic Acids Res. 2015, 43, 2466.

[15] V. Pareek, A. M. Pedley, S. J. Benkovic, Crit. Rev. Biochem. Mol. Biol. 2021, 56, 1.

[16] A. Alissandratos, K. Caron, T. D. Loan, J. E. Hennessy, C. J. Easton, ACS Chem. Biol. 2016, 11, 3289.

[17] T. D. Loan, C. J. Easton, A. Alissandratos, Sci. Rep. 2019, 9, 15621. 
[18] D. Chandra, S. B. Bratton, M. D. Person, Y. Tian, A. G. Martin, M. Ayres, H. O. Fearnhead, V. Gandhi, D. G. Tang, Cell 2006, 125, 1333.

[19] A. Hofer, M. Crona, D. T. Logan, B.-M. Sjöberg, Crit. Rev. Biochem. Mol. Biol. 2012, 47, 50.

[20] G. S. Brush, S. K. Bhatnagar, M. J. Bessman, J. Bacteriol. 1990, 172, 2935.

[21] D. V. Liu, J. F. Zawada, J. R. Swartz, Biotechnol. Prog. 2005, 21, 460.

[22] S. K. Dondapati, M. Stech, A. Zemella, S. Kubick, BioDrugs 2020, 34, 327.

[23] S. A. Lesley, in Vitro Transcr. Transl. Protoc. (Ed.: M.J. Tymms), Humana Press, Totowa, NJ, 1995, pp. 265-278.

[24] B. J. L. Dopp, D. D. Tamiev, N. F. Reuel, Biotechnol. Adv. 2019, 37, 246.

[25] M. H. Buckstein, J. He, H. Rubin, J. Bacteriol. 2008, 190, 718.

[26] Y. Shimizu, T. Kanamori, T. Ueda, Methods 2005, 36, 299.

[27] C. A. Heid, J. Stevens, K. J. Livak, P. M. Williams, Genome Res. 1996, 6, 986.

[28] B. Udugama, P. Kadhiresan, H. N. Kozlowski, A. Malekjahani, M. Osborne, V. Y. C. Li, H. Chen, S. Mubareka, J. B. Gubbay, W. C. W. Chan, ACS Nano 2020, 14, 3822.

[29] T. D. Schmittgen, K. J. Livak, Nat. Protoc. 2008, 3, 1101.

[30] J. E. Szabó, É. V. Surányi, B. S. Mébold, T. Trombitás, M. Cserepes, J. Tóth, Nucleic Acids Res. 2020, 48, e45.

[31] B. Kim, L. A. Nguyen, W. Daddacha, J. A. Hollenbaugh, J. Biol. Chem. 2012, 287, 21570.

[32] B. Breiner, K. Johnson, M. Stolarek, A.-L. Silva, A. Negrea, N. M. Bell, T. H. Isaac, M. Dethlefsen, J. Chana, L. A. Ibbotson, R. N. Palmer, J. Bush, A. J. Dunning, D. M. Love, O. Pachoumi, D. J. Kelly, A. Shibahara, M. Wu, M. Sosna, P. H. Dear, F. Tolle, E. Petrini, M. Amasio, L. R. Shelford, M. S. Saavedra, E. Sheridan, J. Kuleshova, G. J. Podd, B. W. Balmforth, C. A. Frayling, Nucleic Acids Res. 2019, 47, e101.

[33] J. G. Ferry, in Methods Enzymol. (Eds.: A.C. Rosenzweig, S.W. Ragsdale), Academic Press, 2011, pp. 219-231.

[34] K. Motomura, R. Hirota, M. Okada, T. Ikeda, T. Ishida, A. Kuroda, Appl. Environ. Microbiol. 2014, 80, 2602.

[35] L. He, X. Wei, X. Ma, X. Yin, M. Song, H. Donninger, K. Yaddanapudi, C. J. McClain, X. Zhang, J. Am. Soc. Mass Spectrom. 2019, 30, 987. 


\title{
Supporting Information
}

\section{DNA as a Recyclable Natural Polymer}

\section{Weina Liu, Simone Giaveri, Daniel Ortiz, Francesco Stellacci*}

\author{
W. Liu, S. Giaveri, F. Stellacci
}

Institute of Materials, École Polytechnique Fédérale de Lausanne (EPFL), Lausanne 1015, Switzerland.

Institute of Bioengineering, École Polytechnique Fédérale de Lausanne (EPFL), Lausanne 1015, Switzerland.

E-mail: francesco.stellacci@epfl.ch

\section{Ortiz}

Institute of Chemical Sciences and Engineering, École Polytechnique Fédérale de Lausanne (EPFL), Lausanne 1015, Switzerland.

Keywords: DNA hydrolysis, one-pot phosphorylation, DNA recycling, qPCR

\section{Materials}

Chemicals: 2'-Deoxyguanosine 5'-monophosphate sodium salt hydrate (dGMP), Thymidine 5'-monophosphate disodium salt hydrate (dTMP), 2'-Deoxycytidine 5'-monophosphate sodium salt (dCMP), 2'-Deoxyadenosine 5'-monophosphate (dAMP), Acetylephosphate Lituium Potassium salt (AceP), Sodium chloride (DNase, RNase, and protease free), Sodium hydroxide solution $(5.0 \mathrm{M})$, Acetic acid, Tetrabutylammonium dihydrogenphosphate solution $(1.0 \mathrm{M}$ in water), Deoxynucleotide mix reagent (dNTPs, $10 \mathrm{mM}$ for each), Adenosine 5'-triphospate disodium (ATP, $100 \mathrm{mM}$ ) were purchased from Sigma-Aldrich. DNA: Calf thymus DNA is purchased from Sigma-Aldrich. Cas number 73049-39-5, Catalog number D8661. As described from the vendor, the Calf thymus DNA has been fragmented by sonication. E. coli genomic DNA is purchased from thermo scientific, Cas number 9007-49-2, Catalog number J14380.MA. As described from the vendor, the E. coli genomic DNA is purified from E. coli type B cells, ATCC 11303 strain. It has a single chromosome, and the genome is 4,600,000 bp long. This genomic DNA is fragmented to some degree during purification, yet it is characterized as a high molecular weight DNA. Enzyme: Exonuclease III $(200 \mathrm{U} / \mu \mathrm{L})$, Exonuclease I $(20 \mathrm{U} / \mu \mathrm{L})$, DreamTaq DNA Polymerase $(5 \mathrm{U} / \mu \mathrm{L})$ were purchased from Thermo Fisher Scientific. T4 dNMP (deoxy-Nucleotide Monophosphate) Kinase was purchased from Jena Bioscience. E. coli S30 Extract System for Circular DNA (with luciferase plasmid DNA template) was purchased from Promega Corporation. Chemicals for gel electrophoresis: $400 \mu \mathrm{L}-\mathrm{SYBR}$ Safe DNA Gel Stain, DNA Loading Dye and SDS Solution (6X), TAE Buffer (Tris-acetate-EDTA) (50x), TrackIt 100 bp DNA Ladder, PowerTrack ${ }^{\mathrm{TM}}$ SYBR Green Master Mix were purchased from Thermo Fisher Scientific. Agarose was purchased from Bio-Rad Laboratories. Amicon Ultra-0.5 mL Centrifugal Filters (3 K cutoff) was purchased from Merck. Nuclease-Free Water $(10 \times 50 \mathrm{ml})$ was purchased from QIAGEN. Self-made phosphorylation buffer: $55 \mathrm{mM}$ HEPES, Magnesium acetate $15 \mathrm{mM}, \mathrm{pH}$ 7.5. HEPES buffer $(1 \mathrm{M})$ was purchased from Thermo Fisher Scientific. NuPAGE 4-12\% Bis-Tris Protein Gels, NuPAGETM MES SDS Running Buffer (20X) were purchased from Thermo Fisher Scientific. Details of materials, experiments, and 
instrument information about GFP plasmid DNA amplification and GFP expression in experiment section.

\section{Instruments:}

Eppendorf Thermomixer (RTM F1.5, 220 - 240 V/50 - $60 \mathrm{~Hz}$ ) was purchased from Eppendorf. DNA ultrasonication was performed by Vibra-Cell ${ }^{\mathrm{TM}} 75286$ ultrasonic Liquid Processors. Horizontal gel electrophoresis system was purchased from Bio-Rad. Gel images was taken from GelDoc Go, Bio-rad. PCR was performed by Proflex 3X32-well PCR thermal cycler system (ThermoFisher Scientific). Quantitative PCR was performed by QuantStudio 7 qPCR instrument (Applied Biosystems). HPLC was performed by Infinite 1260 HPLC with C 18 column, Agilent. Details of LC-MS system in the experiment section.

\section{Experiment:}

\section{DNA hydrolysis}

Calf thymus DNA hydrolysis and HPLC characterization: Calf thymus DNA (sheared, 0.966 $\mathrm{mg} / \mathrm{mL}, 75 \mu \mathrm{L}$ ) was mixed with $3 \mu \mathrm{L}$ Exonuclease III (600 Unit), $3 \mu \mathrm{L}$ Exonuclease I (60 Unit), $9 \mu \mathrm{L}$ nuclease free water, and $10 \mu \mathrm{L} 10 \times$ Exonuclease III buffer. The final reaction volume is $100 \mu \mathrm{L}$ with $1 \times$ Exonuclease III buffer $\left(0.66 \mathrm{mM} \mathrm{MgCl}_{2}, 66 \mathrm{mM}\right.$ Tris-HCl, $\mathrm{pH} 8.0$ at $\left.30^{\circ} \mathrm{C}\right)$. The Calf DNA hydrolysis mixture (referred as dNMPs_calf DNA-1) was incubated in thermomixer at $37^{\circ} \mathrm{C}, 350 \mathrm{RPM}$ overnight. Following the DNA hydrolysis mixture was incubated in $80^{\circ} \mathrm{C}$ for 20 mins to inactivate the Nuclease. The dNMPs recycled from Calf DNA was characterized by HPLC. As the retention peaks of $d G M P$ and dTMP were not very well separated (Figure S3), the concentration of dNMPs was quantified by LC-MS.

Calf thymus DNA hydrolysis and LC-MS characterization: Calf thymus DNA (sheared, 2.5 $\mathrm{mg} / \mathrm{mL}, 150 \mu \mathrm{L}$ ) was mixed with $15 \mu \mathrm{L}$ Exonuclease III (3000 Unit), $15 \mu \mathrm{L}$ Exonuclease I (300 Unit), $90 \mu \mathrm{L}$ nuclease free water, and $30 \mu \mathrm{L} 10$ X Exonuclease III buffer. The final reaction volume is $300 \mu \mathrm{L}$ with $1 \mathrm{X}$ Exonuclease III buffer $\left(0.66 \mathrm{mM} \mathrm{MgCl}_{2}, 66 \mathrm{mM}\right.$ Tris-HCl, $\mathrm{pH} 8.0$ at $30^{\circ} \mathrm{C}$ ). The Calf DNA hydrolysis mixture was incubated in thermomixer at $37^{\circ} \mathrm{C}, 350 \mathrm{RPM}$ overnight. Following the DNA hydrolysis mixture was incubated in $80^{\circ} \mathrm{C}$ for 20 mins to inactivate the Nuclease. The dNMPs recycled from Calf DNA was referred as dNMPs_calf DNA-2 and quantified by LC-MS (Figure S1b). DNA hydrolysis substrate was prepared as dilution buffer for the dNMPs standard solution. Reaction mixture of DNA hydrolysis buffer without calf DNA (with substrate condition equal to the DNA hydrolysis condition) was prepared by mixing $3 \mu \mathrm{L}$ Exonuclease III, $3 \mu \mathrm{L}$ Exonuclease I, $48 \mu \mathrm{L}$ nuclease free water, and $6 \mu \mathrm{L} 10 \mathrm{X}$ Exonuclease III buffer. The reaction mixture was purified by ultrafiltration (Amicon, $3 \mathrm{KD}$ ), diluted for 5000 times, and later used as dilution buffer for the preparation of dNMPs standard solution. Stock solution of dNMPs standard (1 mM for each) was prepared in milli-Q water. Further the stock solution was stepwisely diluted to $1000,800,600,400,200,100,50$ $\mathrm{nM}$ by the diluted DNA hydrolysis buffer. The reason to prepare dNMPs standard solution in DNA hydrolysis buffer, is to maintain the sample and references in the same condition, so that the influences from ion suppression for LC-MS quantification results can be avoided.

\section{2. dNMPs Phosphorylation}


dNMPs-phosphorylation and HPLC quantification: The dNMPs $(100 \mathrm{mM}, 0.8 \mu \mathrm{L}$ for each) was mixed with $2 \mu \mathrm{L}$ E. coli S30 Extract, $0.66 \mu \mathrm{L}$ T4 dNMP Kinase (66 Unit), $10 \mu \mathrm{L}$ ATP (10 $\mathrm{mM}$ ), and $25.6 \mu \mathrm{L}$ Acetyl phosphate Lithium potassium (AceP, $50 \mathrm{mM}$ ), $20 \mu \mathrm{L}$ phosphorylation buffer, and $138.54 \mu \mathrm{L}$ nuclease-free water for phosphorylation. The dNMPs phosphorylation reaction mixture with final volume $200 \mu \mathrm{L}$, dNMPs $(0.4 \mathrm{mM}$ for each), ATP $(0.5 \mathrm{mM})$, AceP (6.4 mM, 2 equivalent) was incubated in thermomixer at $400 \mathrm{RPM}, 37^{\circ} \mathrm{C}$ for 4 hours. All the hydrolysis and phosphorylation enzymes were removed by ultrafiltration (Amicon, $3 \mathrm{KD}$ cutoff). Further the filtrated reaction mixture referred as dNTPs_dNMPs was diluted for 50 times and injected to HPLC $(50 \mu \mathrm{L})$ to evaluate the phosphorylation efficiency.

dNMPs_calf DNA phosphorylation and HPLC quantification: The hydrolyzed Calf DNA (dNMPs_calf DNA-1, 66.7 $\mu \mathrm{L}$ ) was mixed with $1 \mu \mathrm{L}$ E. coli S30 Extract, $1 \mu \mathrm{L}$ T4 NMP Kinase (3 times dilution, 33 Unit), $5 \mu \mathrm{L}$ ATP $(10 \mathrm{mM})$, and $12.8 \mu \mathrm{L}$ Acetyl phosphate Lithium potassium (AceP, $50 \mathrm{mM}$ ), $10 \mu \mathrm{L}$ phosphorylation buffer, $3.5 \mu \mathrm{L}$ nuclease-free water for phosphorylation. The dNMPs_calf DNA phosphorylation reaction mixture with final volume $100 \mu \mathrm{L}$, estimated dNMPs (in average $0.4 \mathrm{mM}$ for each), ATP $(0.5 \mathrm{mM})$, AceP $(6.4 \mathrm{mM}, 2$ equivalent) was incubated in thermomixer at $400 \mathrm{RPM}, 37^{\circ} \mathrm{C}$ for 4 hours. Afterwards all hydrolysis enzymes and phosphorylation enzymes, and non-hydrolyzed DNA was removed by ultrafiltration (Amicon, $3 \mathrm{KD}$ cutoff, $5000 \mathrm{RPM}$ for $30 \mathrm{~min}$ in $4^{\circ} \mathrm{C}$ ). Further the filtrated reaction mixture (referred as dNTPs_calf DNA-1) was diluted for 50 times and injected to HPLC $(50 \mu \mathrm{L})$ for quantification of each dNTP. The recycled nucleotide mixture dNTPs_calf DNA-1 was directly used for PCR to amplify GFP DNA plasmid.

\section{LC-MS}

The LC-MS characterization of recycled dNMPs experiments were carried out using a shorter version of the protocol published by Zhang et at. ${ }^{[1]}$ Analysis were conducted on a Xevo G2-S QTOF mass spectrometer coupled to the Acquity UPLC Class Binary Solvent manager and BTN sample manager (Waters, Corporation, Milford, MA). The injection volume was $5 \mu \mathrm{L}$. Mass spectrometer detection was operated in negative ionization using the ZSpray ${ }^{\mathrm{TM}}$ dualorthogonal multimode ESI/APCI/ESCi® source. The TOF mass spectra were acquired in the resolution mode over the range of $\mathrm{m} / \mathrm{z} 100-500$ at an acquisition rate of $0.1 \mathrm{sec} / \mathrm{spectra}$. The instrument was calibrated using a solution of sodium format $(0.01 \mathrm{mg} / \mathrm{L}$ in isopropanol/H2O 90:10). A mass accuracy better than 5 ppm was achieved using a Leucine Enkephalin solution as lock-mass $(200 \mathrm{pg} / \mathrm{mL}$ in $\mathrm{ACN} / \mathrm{H} 2 \mathrm{O}$ (50:50)) infused continuously using the LockSpray source. Source settings were as follows: cone, $25 \mathrm{~V}$; capillary, $3 \mathrm{kV}$, source temperature, $140^{\circ} \mathrm{C}$; desolation temperature, $400^{\circ} \mathrm{C}$, cone gas, $70 \mathrm{~L} / \mathrm{h}$, desolation gas, $500 \mathrm{~L} / \mathrm{h}$. Data were processed using MassLynx ${ }^{\mathrm{TM}} 4.1$ software and QuanLynx application for quantification. The separation was achieved using an ACQUITY Premier HSS $1.8 \mu \mathrm{m}$ vanguard FIT column, $2.1 \mathrm{~mm} \times 100$ $\mathrm{mm}$ (Waters) heated at $40^{\circ} \mathrm{C}$. Mobile phase consisted of $0.1 \%$ formic acid in water as eluent A and $0.1 \%$ formic acid in acetonitrile/water $(6: 4)$ as eluent $\mathrm{B}$. The separation was carried out at $0.3 \mathrm{~mL} / \mathrm{min}$ over a $15 \mathrm{~min}$ total run time using the following program: from 0 to $5 \mathrm{~min}, 100$ 95\% A; 5-10 $\min , 95 \% \mathrm{~A} ; 10-10.1 \mathrm{~min}, 95-100 \% \mathrm{~A} ; 10.1-15 \mathrm{~min}, 100 \% \mathrm{~B}$ to re-equilibrate the system in initial conditions.

Standard stock solutions of dNMPs mixture were prepared at a concentration of $1 \mathrm{mM}$ in MilliQ water. Stock solutions were further diluted in DNA hydrolysis buffer (5000 times diluted) and calibration curves achieved by a serial dilution in the $50-1000 \mathrm{nM}$ concentration range (Figure S1a). The DNA hydrolysis product dNMPs_calf DNA-2 were diluted in Milli-Q water for 5000 times before LC-MS analysis in order to fit into the calibration curves. Extracted ions chromatograms (XIC) were based on a retention time (RT) window of \pm 0.25 min with a massextraction-window (MEW) of $\pm 25 \mathrm{ppm}$ centered on $\mathrm{m} / \mathrm{z}$ of each nucleotide. The average peak 
area of three replicate injections at each concentration was used for each data point. Calibration curves were fitted with a polynomial order 2 equation, with R2 $>0.98$ for all nucleotides.
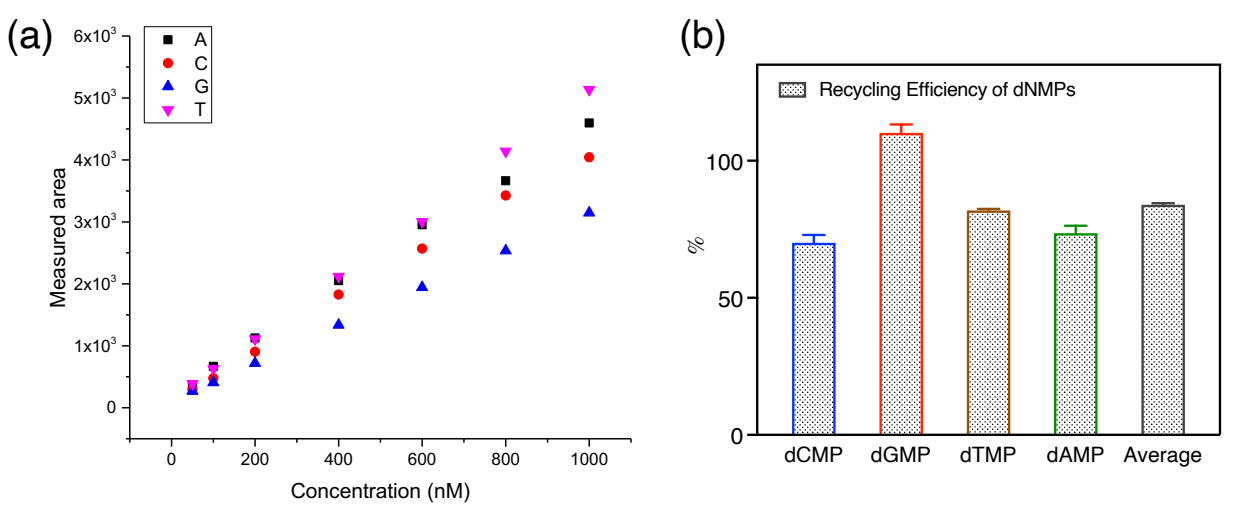

Figure S1. (a) Calibration curve of dNMPs from LC-MS, concentration (50, 100, 200, 400, 600, 800, $1000 \mathrm{nM}$ ). (b) Recycling rate of dNMPs from calf DNA.

\section{HPLC quantification}

The concentration of dNTPs was quantified by HPLC with C 18 column. Mobile phase Buffer A: $5 \mathrm{mM}$ t-butyl ammonium phosphate, $10 \mathrm{mM} \mathrm{KH}_{2} \mathrm{PO}_{4}$, and $0.25 \%$ methanol adjusted to $\mathrm{pH}$ 6.9. Buffer B: $5 \mathrm{mM}$ t-butyl ammonium phosphate, $50 \mathrm{mM} \mathrm{KH}_{2} \mathrm{PO}_{4}$, and $30 \%$ methanol $(\mathrm{pH}$ 7.0). From 0 to 15 mins gradients changed from $40 \% / 60 \%$ to $20 \% / 80 \%$ of buffer $\mathrm{A} / \mathrm{B}$ and run under the same gradient condition to $20 \mathrm{~min}$, and changed back to the starting condition of $40 \% / 60 \%$, flow rate $0.5 \mathrm{ml} / \mathrm{min}$.

Mixture of dNMPs $(8 \mu \mathrm{M}$ for each, $50 \mu \mathrm{L})$ was injected to HPLC. The retention time of nucleotide monophosphate are as following: dCMP_3.4 mins, dGMP_4.2 mins, dTMP_4.6 mins, dAMP_6.7 mins. Mixture of dNTPs and ATP $(2.5,5,10,20,40 \bar{\mu} \mathrm{M})$ standard solution was injected to HPLC to generate the calibration curves for quantification (Figure S3). Calibration curve of dNTPs as well as ATP was generated by integrated area. The retention time of nucleotide triphosphate (dNTPs and ATP) are as following: dCTP_9.5 mins, dGTP_12.4 mins, dTTP_14.3 mins, ATP_15.7 mins, dATP_18.2 mins (Figure S2). Phosphorylation products of dNTPs_dNMPs and dNTPs_calf DNA-1 were injected to HPLC for quantification.

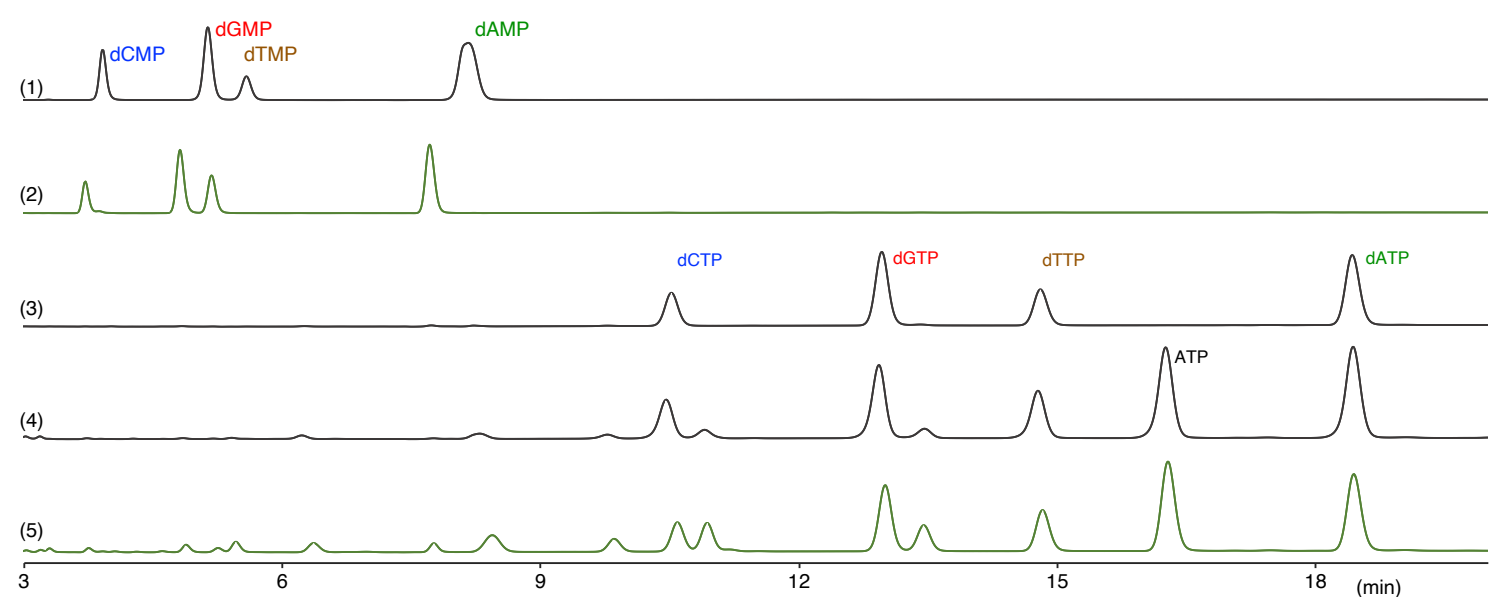


Figure S2. HPLC retention time of (1) dNMPs standards, (2) dNMPs_calf DNA, (3) dNTPs standards, (4) dNTPs_dNMPs phosphorylation, and (5) dNTPs_calf DNA.

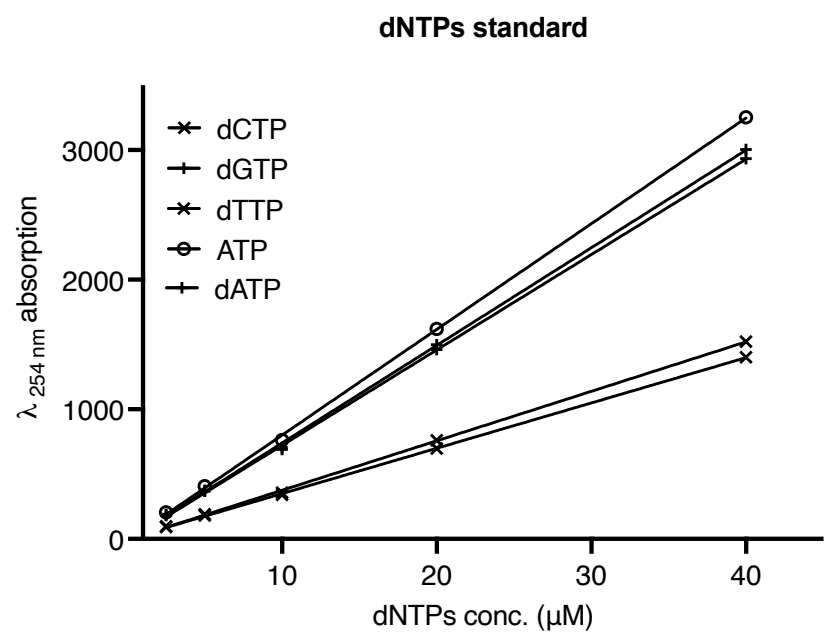

Figure S3. Calibration curve of dNTPs and ATP standard solution (concentration 2.5, 5, 10, $20,40 \mu \mathrm{M})$.

\section{Gel electrophoreses}

Samples of calf DNA (before and after hydrolysis) were mixed with DNA loading dye and loaded to an agarose gel (2\%). The loading amount was adjusted to equal amount of calf DNA before and after hydrolysis. The agarose gel was run in 1 x TAE buffer at $120 \mathrm{~V}$ for $40 \mathrm{~min}$. Afterwards, the gel was stained by 1x Sybr safe solution for 40 min under slow shaking. Following the gel image was taken by GelDoc Go under Sybr safe channel for $1 \mathrm{~s}$ exposure time (Figure 1b). lane 1, TrackIt 100 bp ladder, $2 \mu \mathrm{L}$; lane 2, calf DNA, $0.966 \mathrm{mg} / \mathrm{mL}, 2.1 \mu \mathrm{L}$; lane 3 , hydrolyzed calf DNA, $2.73 \mu \mathrm{L}$ ( $1.3 \times$ dilution by hydrolysis).

\section{Recycled dNTPs for GFP DNA amplification and GFP expression}

\section{Materials:}

$P C R$ reagents. gBlock encoding GFP, and primers (fwd and rev) were purchased from IDT Integrated DNA Technologies. 5x Phusion HF Buffer, dNTP Mix (10 mM), Phusion High-

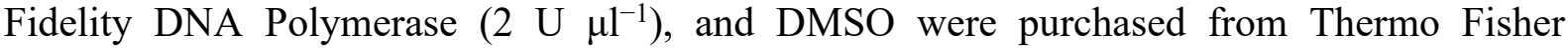
Scientific; nuclease-free water was supplied by Sigma-Aldrich. 5x GelPilot DNA Loading Dye, and QIAquick PCR Purification Kit were purchased from Qiagen; GeneRuler 1 kb DNA Ladder (ready-to-use), and SYBR Safe DNA Gel Stain from Thermo Fisher Scientific. UltraPure Agarose was supplied by Invitrogen. 50x TAE buffer was purchased from Jena Bioscience. Cell-Free expression. Magnesium acetate, Potassium glutamate, DL-Dithiothreitol (DTT), Creatine phosphate, Folinic acid, Spermidine, HEPES buffer, Protector RNase Inhibitor, and the 20 proteinogenic AAs were purchased from Sigma-Aldrich. ATP, GTP, CTP, and UTP were supplied by Thermo Fisher Scientific. tRNAs were purchased from Roche. PUREfrex ${ }^{\mathrm{TM}}$ Solution II (enzymes), and PUREfrex ${ }^{\mathrm{TM}}$ Solution III (ribosomes) were supplied by Kaneka Eurogentec SA. Tools. Protein LoBind Tubes were purchased from Eppendorf. Nunc ${ }^{\mathrm{TM}} 384-$ 
well optical bottom plates were supplied by Thermo Fisher Scientific. SealPlate sealing film was purchased from Sigma-Aldrich.

\section{Recycled dNTPs for GFP plasmid DNA amplification}

Positive control PCR batch $(20 \mu \mathrm{l})$. The reaction was assembled by mixing $1 \mu \mathrm{l}$ DNA linear gBlock template $\left(1 \mathrm{ng} \mu \mathrm{l}^{-1}\right), 0.2 \mu \mathrm{l}$ fwd. primer $(50 \mu \mathrm{M}), 0.2 \mu \mathrm{l}$ rev. primer $(50 \mu \mathrm{M}), 4 \mu \mathrm{l} 5 \mathrm{x}$ Phusion HF Buffer, $0.3 \mu \mathrm{l}$ dNTP Mix $(10 \mathrm{mM}), 1 \mu \mathrm{DMSO}, 0.15 \mu 1$ Phusion High-Fidelity DNA Polymerase $\left(2 \mathrm{U}^{-1}\right)$, and $13.15 \mu \mathrm{l}$ nuclease-free water in a small PCR vial. Sample PCR batch $(20 \mu \mathrm{l})$. The reaction was assembled by mixing $1 \mu \mathrm{l}$ DNA linear gBlock template $(1 \mathrm{ng}$ $\left.\mu 1^{-1}\right), 0.2 \mu \mathrm{l}$ fwd. primer $(50 \mu \mathrm{M}), 0.2 \mu \mathrm{l}$ rev. primer $(50 \mu \mathrm{M}), 4 \mu 15 \mathrm{x}$ Phusion HF Buffer, 12.5 $\mu \mathrm{l}$ dNTP Mix (0.24 mM), $1 \mu \mathrm{l}$ DMSO, $0.15 \mu$ Phusion High-Fidelity DNA Polymerase (2 U $\left.\mu \mathrm{l}^{-1}\right)$, and $0.95 \mu \mathrm{l}$ nuclease-free water in a small PCR vial. PCR thermal cycle $(20 \mu \mathrm{l} \mathrm{batch})$. Initialization was run at $98^{\circ} \mathrm{C}$ for $2 \mathrm{~min}$, denaturation at $98^{\circ} \mathrm{C}$ for $20 \mathrm{~s}$, annealing at $47^{\circ} \mathrm{C}$ for $30 \mathrm{~s}$, and extension at $72^{\circ} \mathrm{C}$ for $45 \mathrm{~s}$. Denaturation, annealing, and extension were repeated $35 \mathrm{x}$. The reaction temperature was kept at $72^{\circ} \mathrm{C}$ for additional $7 \mathrm{~min}$ and decreased to $4^{\circ} \mathrm{C}$ for storage. The whole thermal cycle was run into Thermo Fisher Scientific ProFlex ${ }^{\mathrm{TM}}$ PCR System. Casting of the gel. The size of the amplified template was checked by running an agarose gel, prior to purification of the template from the PCR batch. 1\% Agarose gel was cast by mixing $0.4 \mathrm{~g}$ of Agarose into $40 \mathrm{ml}$ of $1 \mathrm{x}$ TAE buffer; the suspension was heated in the microwave at $800 \mathrm{~W}$ for $90 \mathrm{~s}$ approximately and added with $4 \mu \mathrm{l}$ of SYBR Safe DNA Gel Stain. Samples preparation. $1 \mu \mathrm{l}$ of PCR reaction was diluted adding $3 \mu \mathrm{l}$ of nuclease- free water, and $1 \mu \mathrm{l}$ of 5x GelPilot DNA Loading Dye; $5 \mu \mathrm{l}$ of GeneRuler $1 \mathrm{~kb}$ DNA Ladder were used as reference. Running conditions. The gel was run at $60 \mathrm{~V}$ for $5 \mathrm{~min}$ followed by $120 \mathrm{~V}$ for $30 \mathrm{~min}$ in the Thermo Scientific EasyCast gel system. Imaging. The gel was imaged by using Thermo Fisher Scientific Benchtop 3UV transilluminator equipped with Kodak gel logic 100 imaging system, $\lambda=302 \mathrm{~nm}, 4 \mathrm{~s}$ exposure. Purification. The PCR product was purified by combining 4 PCR batches, doubling the final volume by adding nuclease-free water, and following the QIAquick PCR Purification Kit protocol. DNA was eluted by using $15 \mu$ of elution buffer per spin column. The final DNA concentration was measured using Witec NanoDrop 1000 spectrophotometer.

\section{Cell-free protein TX-TL}

Energy solution preparation. The following solutions were prepared. SolutionA(-Salts - tRNAs - AAs) (2 ml): Creatine phosphate (147.06 mM), Folinic acid (0.15 mM), Spermidine (14.71 $\mathrm{mM})$, DTT (7.4 mM), ATP (14.71 mM), GTP (14.71 mM), CTP (7.4 mM), UTP (7.4 mM), and HEPES (pH 7.6, 367.65 mM). Salts solution $(2 \mathrm{ml})$ : Magnesium acetate $(184.38 \mathrm{mM})$, and Potassium glutamate $(1.563 \mathrm{M})$. tRNAs solution $(200 \mu \mathrm{l})$ : tRNAs $\left(560 \mathrm{~A}_{260} \mathrm{~mL}^{-1}\right)$. tRNAs were quantified by using UV absorption $\mathrm{A}_{260}$ in Witec NanoDrop 1000 spectrophotometer. The three solutions were combined in a $25 \mu \mathrm{l}$ reaction, by mixing 3.4/1.6/2.5 v/v/v solutionA(-Salts tRNAs - AAs):salts solution:tRNAs solution, in order to get the desired concentrations, adapted from Ueda and coworkers: ${ }^{[2]}$ Creatine phosphate $(20 \mathrm{mM})$, Folinic acid $(0.02 \mathrm{mM})$, Spermidine (2 mM), DTT (1 mM), ATP (2 mM), GTP $(2 \mathrm{mM})$, CTP $(1 \mathrm{mM})$, UTP $(1 \mathrm{mM})$, HEPES $(\mathrm{pH}$ 7.6, $50 \mathrm{mM})$, Magnesium acetate $(11.8 \mathrm{mM})$, Potassium glutamate $(100 \mathrm{mM})$, and tRNAs (56

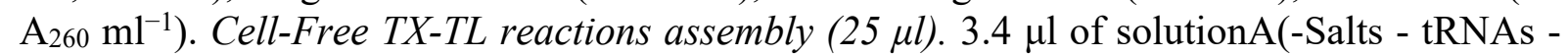
AAs), $1.6 \mu \mathrm{l}$ of salts solution, $2.5 \mu \mathrm{l}$ of tRNAs solution, $1.25 \mu 1$ PUREfrex $^{\mathrm{TM}}$ Solution II (enzymes), $1.25 \mu$ PUREfrex ${ }^{\mathrm{TM}}$ Solution III (ribosomes), $0.5 \mu \mathrm{l}$ RAse inhibitor, $2.5 \mu 1$ of AAs, and $75 \mathrm{ng}$ DNA (samples, and positive controls) were mixed in ice. Nuclease-free water was added to bring the reaction volume to $25 \mu \mathrm{l}$. In the negative controls the DNA was replaced with nuclease-free water. These volumes keep each reagent at the desired concentration in the TX-TL reaction. Cell-Free TX-TL reaction. The reactions were gently mixed, transferred into a 384-well plate, sealed to avoid evaporation, spin down at $3000 \mathrm{rcf}, 25^{\circ} \mathrm{C}$ in Eppendorf 5810R, and incubated at $37^{\circ} \mathrm{C}$ for $8 \mathrm{~h}$ in Thermo Fisher Scientific BioTek Synergy Mx plate reader. 
The plate reader parameters were the following: detection method $=$ fluorescence, $\lambda_{\text {exc }}=488$ $\mathrm{nm}, \lambda_{\mathrm{em}}=507 \mathrm{~nm}, 1 \mathrm{~min}$ interval read, sensitivity $=70 \%$, bottom optic position, fast continuous shaking. Data processing. The TX-TL reactions were all run in duplicates. The expression curves represent the statistical mean of the results at any acquisition time; the shadow represents the standard deviation of the same data.

\section{DNA sequences}

\section{gBlock (GFP)}

(5')gcaccatcagccagaaaaccgaaccagccagaaaacgacctttctgtggatcttaaggctagagtactaatacgactcactatag ggagaccacaacggtttccctctagaaataattttgtttaacttaagaaggaggaaaaaaaatggtctctaaaggtgaagaattattcact ggtgttgtcccaattttggttgaattagatggtgatgttaatggtcacaaattttctgtctccggtgaaggtgaaggtgatgctacttacggta aattgaccttaaaatttatttgtactactggtaaattgccagttccatggccaaccttagtcactactttaacttatggtgttcaatgttttctag atacccagatcatatgaaacaacatgacttttcaagtctgccatgccagaaggttatgttcaagaaagaactattttttcaaagatgacgg taactacaagaccagagctgaagtcaagtttgaaggtgataccttagttaatagaatcgaattaaaaggtattgattttaaagaagatggta acattttaggtcacaaattggaatacaactataactctcacaatgtttacatcatggctgacaaacaaaagaatggtatcaaagttaacttca aaattagacacaacattgaagatggttctgttcaattagctgaccattatcaacaaaatactccaattggtgatggtccagtcttgttaccag acaaccattacttatccactcaatctgccttatccaaagatccaaacgaaaagagagaccacatggtcttgttagaatttgttactgetgctg gtattaccttaggtatggatgaattgtacaaacaccaccatcatcaccactaataacgactcaggctgctacctagcataacccttgggg cctctaaacgggtcttgaggggtttttggcaggaaagaacatgtgagcaaaagg(3')

Forward primer: 5'-gatcttaaggctagagtac-3'

Reverse primer: 5'-caaaaaacccctcaagac-3'

\section{Protein Sequentes (GFP)}

MVSKGEELFTGVVPILVELDGDVNGHKFSVSGEGEGDATYGKLTLKFICTTGKLPVP WPTLVTTLTYGVQCFSRYPDHMKQHDFFKSAMPEGYVQERTIFFKDDGNYKTRAEV KFEGDTLVNRIELKGIDFKEDGNILGHKLEYNYNSHNVYIMADKQKNGIKVNFKIRH NIEDGSVQLADHYQQNTPIGDGPVLLPDNHYLSTQSALSKDPNEKRDHMVLLEFVTA AGITLGMDELYKHHHHHH*

\section{Recycle dNTPs for quantitative PCR (qPCR)}

Based on the quantification of hydrolysis yield (83.9\%) and phosphorylation yield (69.0\%) of DNA recycling process, the DNA recycling condition was adjusted accordingly to obtain recycled dNTPs with estimated final average concentration $0.4 \mathrm{mM}$ for each for qPCR.

dNTPs recycling from calf DNA: Calf DNA $(2.5 \mathrm{mg} / \mathrm{mL}, 150 \mu \mathrm{L})$ was mixed with $15 \mu \mathrm{L}$ Exonuclease III (3000 Unit), $15 \mu \mathrm{L}$ Exonuclease I (300 Unit), $90 \mu \mathrm{L}$ nuclease free water, and $30 \mu \mathrm{L} 10 \mathrm{X}$ Exonuclease III buffer. The final reaction volume is $300 \mu \mathrm{L}$ with $1 \mathrm{X}$ Exonuclease III buffer $\left(0.66 \mathrm{mM} \mathrm{MgCl}_{2}, 66 \mathrm{mM}\right.$ Tris-HCl, $\mathrm{pH} 8.0$ at $\left.30^{\circ} \mathrm{C}\right)$. The DNA hydrolysis mixture (dNMPs_calf DNA-3) was incubated in thermomixer at $37^{\circ} \mathrm{C}, 350 \mathrm{RPM}$ overnight, and following incubation in $80^{\circ} \mathrm{C}$ for $20 \mathrm{~min}$ to inactivate the Nuclease. The DNA hydrolysis mixture referred as dNMPs_calf DNA-3 $(134 \mu \mathrm{L})$ was mixed with $2 \mu \mathrm{L}$ E. coli S30 Extract, $0.66 \mu \mathrm{L}$ T4 dNMP Kinase (66 Unit), $10 \mu \mathrm{L}$ ATP $(10 \mathrm{mM})$, and $25.6 \mu \mathrm{L}$ Acetyl phosphate Lithium potassium (AceP, $50 \mathrm{mM}$ ), $20 \mu \mathrm{L}$ phosphorylation buffer, and $7.74 \mu \mathrm{L}$ nuclease-free water for phosphorylation. The phosphorylation reaction mixture with final volume $200 \mu \mathrm{L}$, with ATP $(0.5 \mathrm{mM})$, AceP (6.4 mM, 2 equivalent), and estimated final concentration of dNTPs $\left(0.4 \mathrm{mM}\right.$ in average), was incubated in thermomixer at $400 \mathrm{RPM}, 37^{\circ} \mathrm{C}$ for 4 hours. Afterwards all the hydrolysis and phosphorylation enzymes were removed by ultrafiltration (Amicon, $3 \mathrm{KD}$ cutoff). Further the filtrated reaction mixture referred as dNTPs_calf DNA-3 was directly applied for $\mathrm{qPCR}$. The $\mathrm{Mg}^{2+}$ concentration originated from hydrolysis and phosphorylation 
buffer as well as storage condition of enzymes was calculated with final concentration of 1.55 $\mathrm{mM}$.

dNTPs recycling from E. coli DNA: Non-sheared E. coli DNA was purchased from thermo scientific. The E. coli DNA ( $5 \mathrm{mg} / \mathrm{mL}, 2 \mathrm{~mL}$ in a $5 \mathrm{~mL}$ glass vial) was firstly sheared by ultrasonication for 30 mins (10 seconds of $90 \%$ amplitude +5 seconds pause) in ice bath. Following the sheared E. coli DNA $(2.5 \mathrm{mg} / \mathrm{mL}, 150 \mu \mathrm{L})$ was mixed with $15 \mu \mathrm{L}$ Exonuclease III (3000 Unit), $15 \mu \mathrm{L}$ Exonuclease I (300 Unit), $90 \mu \mathrm{L}$ nuclease free water, and $30 \mu \mathrm{L} 10 \mathrm{X}$ Exonuclease III buffer. The final reaction volume is $300 \mu \mathrm{L}$ with $1 \mathrm{X}$ Exonuclease III buffer $\left(0.66 \mathrm{mM} \mathrm{MgCl}_{2}, 66 \mathrm{mM}\right.$ Tris-HCl, $\mathrm{pH} 8.0$ at $\left.30^{\circ} \mathrm{C}\right)$. The DNA hydrolysis mixture (dNMPs_E. coli DNA-1) was incubated in thermomixer at $37^{\circ} \mathrm{C}, 350 \mathrm{RPM}$ overnight, and following incubation in $80^{\circ} \mathrm{C}$ for 20 min to inactivate the Nuclease. Further the DNA hydrolysis mixture referred as dNMPs_E. coli DNA $(134 \mu \mathrm{L})$ was mixed with $2 \mu \mathrm{L}$ E. coli S30 Extract, $0.66 \mu \mathrm{L}$ T4 dNMP Kinase (66 Unit), $10 \mu \mathrm{L}$ ATP $(10 \mathrm{mM})$, and $25.6 \mu \mathrm{L}$ Acetyl phosphate Lithium potassium (AceP, $50 \mathrm{mM}$ ), $20 \mu \mathrm{L}$ phosphorylation buffer, and $7.74 \mu \mathrm{L}$ nuclease-free water for phosphorylation. The reaction mixture with final volume $200 \mu \mathrm{L}$, ATP $(0.5 \mathrm{mM})$, AceP $(6.4$ $\mathrm{mM}, 2$ equivalent), and estimated final concentration of dNTPs $(0.4 \mathrm{mM}$ in average), was incubated in thermomixer at $400 \mathrm{RPM}, 37^{\circ} \mathrm{C}$ for 4 hours. Afterwards all the hydrolysis and phosphorylation enzymes were removed by ultrafiltration (Amicon, $3 \mathrm{KD}$ cutoff). Further the filtrated reaction mixture referred as dNTPs_E. coli DNA was directly applied for qPCR. The $\mathrm{Mg}^{2+}$ concentration originated from hydrolysis and phosphorylation buffer as well as storage condition of enzymes was calculated with final concentration of $1.55 \mathrm{mM}$.

qPCR materials: Plasmid luciferase DNA (4864 bp) was from the E. coli S30 extraction kit with luciferase sequence (pBEST luc, $1684 \mathrm{bp}$ ). Primers were designed by IDT PrimerQuest ${ }^{\mathrm{TM}}$ Tool with forward primer starts from 673 of luciferase sequence, reverse primer start from 805 of luciferase sequence, and length of amplicon 133 base pair. Primers were ordered from Biomers Gmbh.

qPCR reaction mixture of recycled dNTPs was prepared as following: qPCR_Calf DNA: dNTPs_calf DNA-3 $(0.4 \mathrm{mM}$ for each, $100 \mu \mathrm{L})$, DreamTaq polymerase $(1 \mu \mathrm{L}, 2.5 \mathrm{U}), 10 \mathrm{X}$ DreamTaq buffer $(10 \mu \mathrm{L})$, Sybr Dye $1000 \times(20 \mu \mathrm{L})$, Nuclease water $(9 \mu \mathrm{L})$ in total $140 \mu \mathrm{L} . q P C R \_E$. coli DNA: dNTPs_E. coli DNA $(0.4 \mathrm{mM}$ for each, $100 \mu \mathrm{L})$, DreamTaq polymerase $(1 \mu \mathrm{L}, 5 \mathrm{U})$, 10x DreamTaq buffer $(10 \mu \mathrm{L})$, Sybr Dye 1000x $(20 \mu \mathrm{L})$, Nuclease water $(9 \mu \mathrm{L})$ in total $140 \mu \mathrm{L}$.

Forward primer: $5^{\prime}-\mathrm{cgc}$ atg cca gag atc cta $\mathrm{tt}-3^{\prime}$

Reverse primer: $5^{\prime}$-aga cga ctc gaa atc cac ata tc $-3^{\prime}$

qPCR kits (duplicate) were prepared by recycled dNTPs as following: 


\begin{tabular}{|l|l|l|l|}
\hline Component & Stock conc. & Volume for 1 reaction & Final conc. \\
\hline Luc template DNA & $1 \mathrm{ng} / \mu \mathrm{L}$, & $1 \mu \mathrm{L}$, & $1 \mathrm{ng}$, \\
& $0.1 \mathrm{ng} / \mu \mathrm{L}$, & $1 \mu \mathrm{L}$, & $0.1 \mathrm{ng}$, \\
& $0.01 \mathrm{ng} / \mu \mathrm{L}$, & $1 \mu \mathrm{L}$, & $0.01 \mathrm{ng}$, \\
& $0.001 \mathrm{ng} / \mu \mathrm{L}$, & $1 \mu \mathrm{L}$, & $0.001 \mathrm{ng}$, \\
& $0 \mathrm{ng} / \mu \mathrm{L}, \mathrm{NTC}$ & $1 \mu \mathrm{L}$ & 0 ng for NTC \\
\hline $\begin{array}{l}\text { qPCR_calf DNA } \\
\text { or qPCR_E. coli DNA }\end{array}$ & $0.285 \mathrm{mM}$ for & $7 \mu \mathrm{L}$ & $0.2 \mathrm{mM}$ for each \\
\hline Primer (for. and rev.) & $2.5 \mu \mathrm{M}$ for each & $1.6 \mu \mathrm{L}$ & $400 \mathrm{nM}$ \\
\hline Nuclease-free water & & $0.4 \mu \mathrm{L}$ & \\
\hline Total & $10 \mu \mathrm{L}$ & $10 \mu \mathrm{L}$ & $10 \mu \mathrm{L}$ \\
\hline
\end{tabular}

Positive control, duplicate

\begin{tabular}{|l|l|l|l|}
\hline Component & Stock conc. & Volume for 1 reaction & Final conc. \\
\hline Luc template DNA & $1 \mathrm{ng} / \mu \mathrm{L}$, & $1 \mu \mathrm{L}$, & $1 \mathrm{ng}$, \\
& $0.1 \mathrm{ng} / \mu \mathrm{L}$, & $1 \mu \mathrm{L}$, & $0.1 \mathrm{ng}$, \\
& $0.01 \mathrm{ng} / \mu \mathrm{L}$, & $1 \mu \mathrm{L}$, & $0.01 \mathrm{ng}$, \\
& $0.001 \mathrm{ng} / \mu \mathrm{L}$, & $1 \mu \mathrm{L}$, & $0.001 \mathrm{ng}$, \\
& $0 \mathrm{ng} / \mu \mathrm{L}, \mathrm{NTC}$ & $1 \mu \mathrm{L}$ & $0 \mathrm{ng}$ for NTC \\
& $0.4 \mathrm{mM}$ for each & $5 \mu \mathrm{L}$ & $0.2 \mathrm{mM}$ for each \\
\hline qPCR master mix & $2.5 \mu \mathrm{M}$ for each & $1.6 \mu \mathrm{L}$ & $400 \mathrm{nM}$ \\
\hline Primer (for. and rev.) & & $2.4 \mu \mathrm{L}$ & \\
\hline Nuclease-free water & & $10 \mu \mathrm{L}$ & $10 \mu \mathrm{L}$ \\
\hline Total & $10 \mu \mathrm{L}$ &
\end{tabular}

Thermocycle condition for qPCR: the qPCR amplification was performed by QuantStudio 7 qPCR system using the following thermal cycling conditions: Initial denature $\left(95^{\circ} \mathrm{C}, 2 \mathrm{~min}\right)$ for 1 cycle, amplification (denature at $95^{\circ} \mathrm{C}$ for $15 \mathrm{~s}$, annealing and amplification at $60{ }^{\circ} \mathrm{C}$ for $30 \mathrm{~s}$ ) for 40 cycles. 
(a)

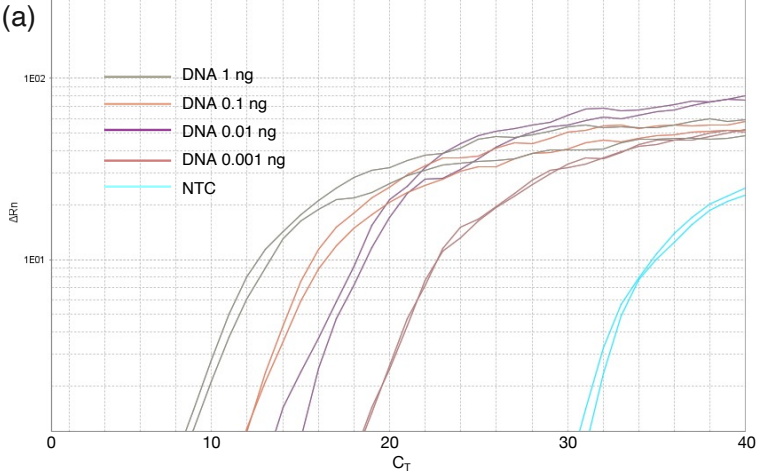

(c)

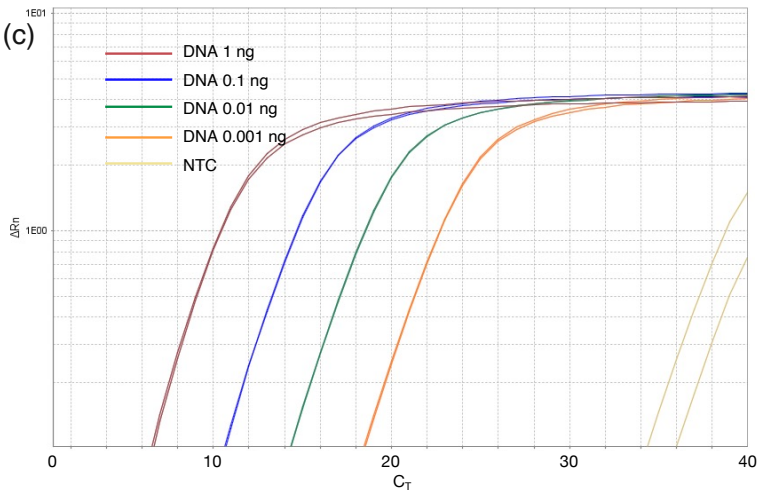

(b)

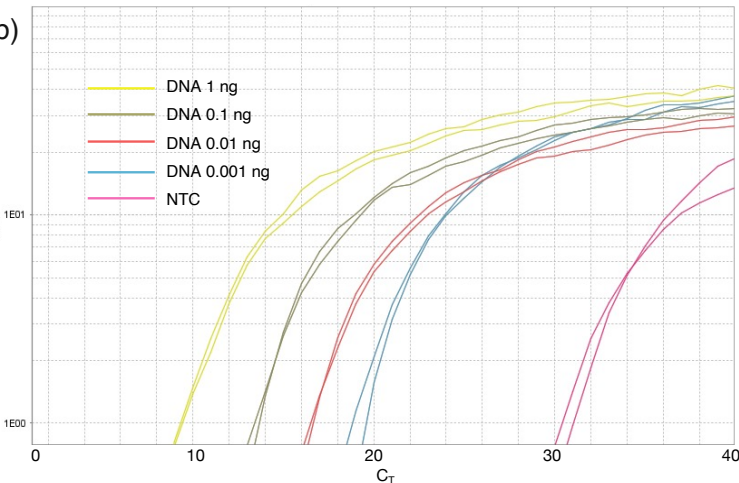

(d)

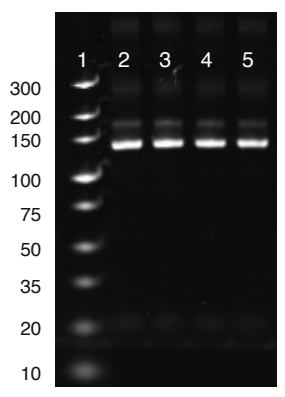

Figure S4. Amplification plots of self-made qPCR kits from dNTPs_calf DNA (a), dNTPs_E. coli DNA (b), and commercial qPCR kit as positive control (c), with DNA template 1, 0.1, 0.01, $0.001 \mathrm{ng}$ and NTC, respectively. (d) Page-gel of qPCR amplification product from positive control with DNA template 1, 0.1, 0.01, $0.001 \mathrm{ng}$ (lane 2-5).

\section{Reference:}

[1] L. He, X. Wei, X. Ma, X. Yin, M. Song, H. Donninger, K. Yaddanapudi, C. J. McClain, X. Zhang, J. Am. Soc. Mass Spectrom. 2019, 30, 987.

[2] Y. Shimizu, T. Kanamori, T. Ueda, Methods 2005, 36, 299. 